\title{
Commentary on: "Further studies are necessary in order to conclude a causal association between the consumption of monosodium L-glutamate (MSG) and the prevalence of the metabolic syndrome in the rural Thai population"
}

Kate S Collison

See related article: http://www.nutritionandmetabolism.com/content/10/1/14

Sir,

I read with considerable interest the epidemiological study by Insawang et al., which demonstrates an association between monosodium glutamate (MSG) intake and the prevalence of the Metabolic Syndrome in a rural Thai population [1]. It is important to point out that Insawang et al. did not claim that MSG causes the Metabolic Syndrome, they did however concluded that "elevated dietary MSG consumption is significantly associated with having the Metabolic Syndrome and being overweight in a Thai rural population".

The present commentary by Dr Rogers [2] concerning the research by Insawang et al. stresses throughout that there is no supporting evidence for a direct causal relationship between MSG intake and the prevalence of Metabolic Syndrome and overweight. The relevance of this oft-repeated statement is questionable since Insawang et al. never proposed a direct causal relationship between MSG intake and the Metabolic Syndrome. Although the authors of this epidemiological study are under no obligation to provide evidence for a causal relationship, a number of issues were raised which make interesting points for discussion. One concern broached by Dr Rogers was that the authors failed to mention in their Discussion a previous publication regarding the Jiangsu Nutritional Study of 1227 Chinese adults [3], which did not show an association between MSG and obesity or weight gain over 5 years. In point of fact, the

Correspondence: kate@kfshrc.edu.sa

Diabetes Research Unit, Department of Cell Biology, King Faisal Specialist Hospital \& Research Centre, P. O. Box. 3354, Riyadh 11211, Saudi Arabia methodology and the conclusions drawn from that particular study were not only questioned, but seriously criticized [4]. Nevertheless, one of the reported findings was a significant association between MSG intake in 2002 and waist circumference five years later [4]. Although it is perhaps understandable that the authors Insawang et al. did not comment on the lack of association between MSG and body weight [3], they did discuss a separate publication concerning the exact same population of 1227 Chinese adults, from the same corresponding author, which showed a significant positive association between MSG intake and hypertension [5]. Elevated blood pressure is one of the five conditions which constitute the Metabolic Syndrome. The National Cholesterol Education Program Adult Treatment Panel III (NCEP) criteria require the presence of at least 3 of the following [6]:

[1] Hypertension, defined as elevated blood pressure defined as $\geq 130 / 85 \mathrm{mmHg}$.

[2] Abdominal obesity defined as waist circumference $\geq 102 \mathrm{~cm}$ or 40 inches (male), or $\geq 88 \mathrm{~cm}$ or 36 inches (female).

[3] Hyperglycemia, defined as elevated Fasting plasma glucose $\geq 110 \mathrm{mg} / \mathrm{dl}$.

[4] Dyslipidemia, defined as elevated triglycerides $\geq$ $150 \mathrm{mg} / \mathrm{dL}$.

[5] Dyslipidemia, defined as presence of high-density lipoprotein cholesterol (HDL-C) $\leq 40 \mathrm{mg} / \mathrm{dL}$ (male), or $\leq 50 \mathrm{mg} / \mathrm{dL}$ (female). 
Importantly, elevated body weight is not one of the criteria for the presence of the Metabolic Syndrome; and indeed, animal model systems indicate that MSG-obese rodents exhibit either lower body weights [7-10], or similar body weights compared to control animals $[11,12]$, depending on the species and experimental conditions. However, impaired cardiovascular autonomic function, elevated arterial pressure, insulin resistance and dyslipidemia have all been documented in rodents exposed to MSG during the neonatal period at a time when the blood brain barrier is immature and vulnerable to excitotoxicity $[13,14]$. Moreover, neonatal exposure to non-physiological levels of MSG is a proven experimental methodology for inducing Metabolic Syndrome in rodents [15-18]; and sometimes referred to as "hypothalamic obesity" $[19,20]$ due to the fact that high levels of glutamate may damage the hypothalamus and other areas of the brain which are rich in glutamate receptors $[11,12]$. Interestingly, increased hypothalamic inflammatory signaling and neuronal injury can also be induced in rodents consuming high fat diets [21-24]; and recent data also provides evidence of hypothalamic low-grade inflammation and gliosis in obese humans [24,25], which may impair the regulation of food intake and energy expenditure.

\section{Conclusion}

[1] The authors of the epidemiological study associating MSG consumption with the prevalence of Metabolic Syndrome were under no obligation to provide a causal relationship between the two. [2] Under experimental conditions in rodents, non-physiological levels of MSG, or high levels of dietary fat may promote damage to the hypothalamus and other areas of the brain regulating energy expenditure. [3] In humans, obesity may be associated with hypothalamic damage. The commentary by Rogers has provided several interesting points of discussion.

\section{Competing interests}

The author declares no competing interests, and has no industrial or personal disclosure.

Received: 5 January 2013 Accepted: 11 January 2013

Published: 22 January 2013

\section{References}

1. Insawang $T$, Selmi $C$, Cha'on U, Pethlert $S$, Yongvanit $P$, Areejitranusorn $P$, Boonsiri P, Khampitak T, Tangrassameeprasert R, Pinitsoontorn C, Prasongwattana V, Gershwin ME, Hammock BD: Monosodium glutamate (MSG) intake is associated with the prevalence of metabolic syndrome in a rural Thai population. Nutr Metab (Lond) 2012, 9:50.

2. Rogers MD: Further studies are necessary to conclude a causal association between the consumption of monosodium L-glutamate (MSG) and the prevalence of metabolic syndrome in the rural Thai population. Nutr Metab (Lond) 2013, in press.

3. Shi Z, Luscombe-Marsh ND, Wittert GA, Yuan B, Dai Y, Pan X, Taylor AW: Monosodium glutamate is not associated with obesity or a greater prevalence of weight gain over 5 years: findings from the Jiangsu Nutrition Study of Chinese adults. Br J Nutr 2010, 104:457-463.

4. Samuels A: Monosodium glutamate is not associated with obesity or a greater prevalence of weight gain over 5 years: findings from the Jiangsu Nutrition Study of Chinese adults-comments by Samuels. Br J Nutr 2010, 104(11):1729.

5. Shi Z, Yuan B, Taylor AW, Dai Y, Pan X, Gill TK, Wittert GA: Monosodium glutamate is related to a higher increase in blood pressure over 5 years: findings from the Jiangsu Nutrition Study of Chinese adults. J Hypertens 2011, 29:846-853.

6. The National Cholesterol Education Program Adult Treatment Panel III (NCEP). http://www.nhlbi.nih.gov/guidelines/cholesterol/atglance.pdf.

7. Kondoh T, Torii K: MSG intake suppresses weight gain, fat deposition, and plasma leptin levels in male Sprague-Dawley rats. Physiol Behav 2008, 95(1-2):135-144.

8. Kim YW, Choi DW, Park YH, Huh JY, Won KC, Choi KH, Park SY, Kim JY, Lee SK Leptin-like effects of MTII are augmented in MSG-obese rats. Regul Pep 2005, 127(1-3):63-70.

9. Dolnikoff M, Martín-Hidalgo A, Machado UF, Lima FB, Herrera E: Decreased lipolysis and enhanced glycerol and glucose utilization by adipose tissue prior to development of obesity in monosodium glutamate (MSG) treated-rats. Int J Obes Relat Metab Disord 2001, 25(3):426-433.

10. Magariños AM, Estivariz F, Morado MI, De Nicola AF: Regulation of the central nervous system-pituitary-adrenal axis in rats after neonatal treatment with monosodium glutamate. Neuroendocrinology 1988, 48(2):105-111

11. Bunyan J, Murrell EA, Shah PP: The induction of obesity in rodents by means of monosodium glutamate. Br J Nutr 1976, 35(1):25-39.

12. Matysková R, Maletínská L, Maixnerová J, Pirník Z, Kiss A, Zelezná B: Comparison of the obesity phenotypes related to monosodium glutamate effect on arcuate nucleus and/or the high fat diet feeding in C57BL/6 and NMRI mice. Physiol Res 2008, 57(5):727-734.

13. Konrad SP, Farah V, Rodrigues B, Wichi RB, Machado UF, Lopes HF, D'Agord Schaan B, De Angelis K, Irigoyen MC: Monosodium glutamate neonatal treatment induces cardiovascular autonomic function changes in rodents. Clinics (Sao Paulo) 2012, 67(10):1209-1214.

14. Seiva FR, Chuffa LG, Braga CP, Amorim JP, Fernandes AA: Quercetin ameliorates glucose and lipid metabolism and improves antioxidant status in postnatally monosodium glutamate-induced metabolic alterations. Food Chem Toxicol 2012, 50(10):3556-3561.

15. Chen W, Wang LL, Liu HY, Long L, Li S: Peroxisome proliferator-activated receptor delta-agonist, GW501516, ameliorates insulin resistance, improves dyslipidaemia in monosodium L-glutamate metabolic syndrome mice. Basic Clin Pharmacol Toxicol 2008, 103(3):240-246.

16. Diniz YS, Faine LA, Galhardi CM, Rodrigues HG, Ebaid GX, Burneiko RC, Cicogna AC, Novelli EL: Monosodium glutamate in standard and highfiber diets: metabolic syndrome and oxidative stress in rats. Nutrition 2005, 21(6):749-755.

17. Fujimoto M, Tsuneyama K, Fujimoto T, Selmi C, Gershwin ME, Shimada Y: Spirulina improves non-alcoholic steatohepatitis, visceral fat macrophage aggregation, and serum leptin in a mouse model of metabolic syndrome. Dig Liver Dis 2012, 44(9):767-774.

18. Sasaki $Y$, Shimada T, lizuka S, Suzuki W, Makihara H, Teraoka R, Tsuneyama K, Hokao R, Aburada M: Effects of bezafibrate in nonalcoholic steatohepatitis model mice with monosodium glutamate-induced metabolic syndrome. Eur J Pharmacol 2011, 662(1-3):1-8.

19. Scomparin DX, Grassiolli S, Gomes RM, Torrezan R, de Oliveira JC, Gravena C, Pêra CC, Mathias PC: Low-Intensity swimming training after weaning improves glucose and lipid homeostasis in MSG hypothalamic obese mice. Endocr Res 2011, 36(2):83-90.

20. Perello M, Castrogiovanni D, Giovambattista A, Gaillard RC, Spinedi E Prolonged but not short negative energy condition restored corticoadrenal leptin sensitivity in the hypothalamic obese rat. Neuroendocrinology 2009, 89(3):276-287.

21. De Souza CT, Araujo EP, Bordin S, Ashimine R, Zollner RL, Boschero AC, Saad MJ, Velloso LA: Consumption of a fat-rich diet activates a proinflammatory response and induces insulin resistance in the hypothalamus. Endocrinology 2005, 146(10):4192-4199.

22. Milanski M, Degasperi G, Coope A, Morari J, Denis R, Cintra DE, Tsukumo DM, Anhe G, Amaral ME, Takahashi HK, Curi R, Oliveira HC, Carvalheira JB, Bordin S, Saad MJ, Velloso LA: Saturated fatty acids produce an 
inflammatory response predominantly through the activation of TLR4 signaling in hypothalamus: implications for the pathogenesis of obesity. J Neurosci 2009, 29(2):359-370.

23. Posey KA, Clegg DJ, Printz RL, Byun J, Morton GJ, Vivekanandan-Giri A, Pennathur S, Baskin DG, Heinecke JW, Woods SC, Schwartz MW, Niswender KD: Hypothalamic proinflammatory lipid accumulation, inflammation, and insulin resistance in rats fed a high-fat diet. Am J Physiol Endocrinol Metab 2009, 296(5):E1003-E1012.

24. Thaler JP, Yi CX, Schur EA, Guyenet SJ, Hwang BH, Dietrich MO, Zhao X, Sarruf DA, Izgur V, Maravilla KR, Nguyen HT, Fischer JD, Matsen ME, Wisse BE, Morton GJ, Horvath TL, Baskin DG, Tschöp MH, Schwartz MW: Obesity is associated with hypothalamic injury in rodents and humans. J Clin Invest 2012, 122(1):153-162.

25. Cazettes F, Cohen Jl, Yau PL, Talbot H, Convit A: Obesity-mediated inflammation may damage the brain circuit that regulates food intake. Brain Res 2011, 1373:101-109.

doi:10.1186/1743-7075-10-13

Cite this article as: Collison: Commentary on: "Further studies are necessary in order to conclude a causal association between the consumption of monosodium L-glutamate (MSG) and the prevalence of the metabolic syndrome in the rural Thai population". Nutrition \& Metabolism 2013 10:13.

\section{Submit your next manuscript to BioMed Central and take full advantage of:}

- Convenient online submission

- Thorough peer review

- No space constraints or color figure charges

- Immediate publication on acceptance

- Inclusion in PubMed, CAS, Scopus and Google Scholar

- Research which is freely available for redistribution 